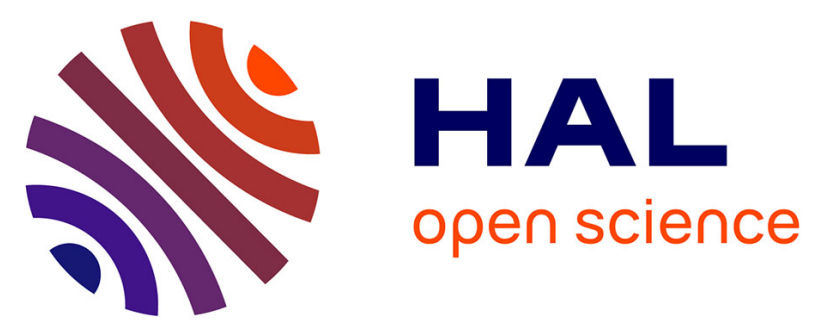

\title{
Combining quantitative risk assessment of human health, food waste and energy consumption: the next step in the development of the food cold chain?
}

Steven Duret, Hong-Minh Hoang, E. Derens-Bertheau, Anthony Delahaye, Onrawee Laguerre, L. Guillier

\section{To cite this version:}

Steven Duret, Hong-Minh Hoang, E. Derens-Bertheau, Anthony Delahaye, Onrawee Laguerre, et al.. Combining quantitative risk assessment of human health, food waste and energy consumption: the next step in the development of the food cold chain?. Risk Analysis, inPress, 39 (4), pp.906-925. 10.1111/risa.13199. hal-02156194

\section{HAL Id: hal-02156194 \\ https://hal.science/hal-02156194}

Submitted on 14 Jun 2019

HAL is a multi-disciplinary open access archive for the deposit and dissemination of scientific research documents, whether they are published or not. The documents may come from teaching and research institutions in France or abroad, or from public or private research centers.
L'archive ouverte pluridisciplinaire HAL, est destinée au dépôt et à la diffusion de documents scientifiques de niveau recherche, publiés ou non, émanant des établissements d'enseignement et de recherche français ou étrangers, des laboratoires publics ou privés. 


\title{
Combining Quantitative Risk Assessment of Human Health, Food Waste, and Energy Consumption: The Next Step in the Development of the Food Cold Chain?
}

\author{
Steven Duret, ${ }^{1, *}$ Hong-Minh Hoang, ${ }^{1}$ Evelyne Derens-Bertheau, ${ }^{1}$ Anthony Delahaye, ${ }^{1}$ \\ Onrawee Laguerre, ${ }^{1}$ and Laurent Guillier ${ }^{2}$
}

\begin{abstract}
The preservation of perishable food via refrigeration in the supply chain is essential to extend shelf life and provide consumers with safe food. However, electricity consumed in refrigeration processes has an economical and an environmental impact. This study focuses on the cold chain of cooked ham, including transport, cold room in supermarket, display cabinet, transport by consumer, and domestic refrigerator, and aims to predict the risk for human health associated with Listeria monocytogenes, the amount of food wasted due to the growth of spoilage bacteria, and the electrical consumption to maintain product temperature through the cold chain. A set of eight intervention actions were tested to evaluate their impact on the three criteria. Results show that the modification of the thermostat of the domestic refrigerator has a high impact on food safety and food waste and a limited impact on the electrical consumption. Inversely, the modification of the airflow rate in the display cabinet has a high impact on electrical consumption and a limited impact on food safety and food waste. A cost-benefit analysis approach and two multicriteria decision analysis methods were used to rank the intervention actions. These three methodologies show that setting the thermostat of the domestic refrigerator to $4{ }^{\circ} \mathrm{C}$ presents the best compromise between the three criteria. The impact of decisionmaker preferences (criteria weight) and limitations of these three approaches are discussed. The approaches proposed by this study may be useful in decision making to evaluate global impact of intervention actions in issues involving conflicting outputs.
\end{abstract}

KEY WORDS: Cold chain; food sustainability; multicriteria decision analysis

\section{INTRODUCTION}

The food chain system is far different today than it was decades ago in most developed and developing countries (Anonymous, 2007; Doyle

\footnotetext{
${ }^{1}$ Irstea, Refrigeration Processes Engineering Research Unit, Antony cedex, France.

${ }^{2}$ Laboratory for Food Safety, Université Paris-Est, MaisonsAlfort, France.

*Address correspondence to Steven Duret, Irstea, Refrigeration Processes Engineering Research Unit, 1 rue Pierre Gilles de Gennes, CS 1003092761 Antony cedex, France; tel: 土33(0)140966015; steven.duret@irstea.fr.
}

et al., 2015; Ercsey-Ravasz, Toroczkai, Lakner, \& Baranyi, 2012). Along the past 50 years, in parallel to changes in consumer behavior and demands, major evolutions occurred in the way food is produced, processed, stored, transported, and marketed (Hueston \& McLeod, 2012; Ragaert, Verbeke, Devlieghere, \& Debevere, 2004). In line with those changes, food policy standards evolved, influenced by food safety (i.e., the assurance that food will not cause harm to the consumer when it is prepared and consumed according to its intended use) to prevent recurrent foodborne outbreaks (Guillier et al., 2016). Among many highlights in the development of food safety 
can be quoted the first hygiene rules in 1964 after the creation of the Codex Alimentarius (initially limited to fresh meat), the adoption in 2000 by the European Commission of the "White paper on food safety," or more recently in the United States with the Food Safety Modernization Act (Wiseman, 2015). In this context, risk analysis gained international recognition as the most effective tool for managing food safety issues (Food and Agriculture Organization for the United Nations [FAO]/World Health Organization [WHO], 1999). This approach is used to estimate risks for human health and safety, identify and implement appropriate measures to control the risk, and communicate with stakeholders about the risks and measures applied.

The use of temperature control without interruption of perishable foods via refrigeration in the food supply chain during transport, storage, and distribution (i.e., food cold chain) is essential to extend shelf life and provide consumers with safe food of high organoleptic quality. The use of refrigeration reduces rates at which changes occur in perishable foods such as growth of microorganisms (e.g., pathogens and alteration flora), ripening rates, browning reactions, or water losses (James \& James, 2010; Laguerre, Hoang, \& Flick, 2013). It is estimated that $40 \%$ of food products require refrigeration (James \& James, 2010; Mattarolo, 1990), and that $9 \%$ of losses of perishable foods is due to a lack of refrigeration in developed countries (International Institute of Refrigeration [IIR], 2009). However, the refrigeration of food through the cold chain has an environmental impact. More specifically, refrigeration accounts for $15 \%$ of the electricity consumed and the food cold chain represents $1 \%$ of $\mathrm{CO}_{2}$ emission worldwide (Coulomb, 2008; James \& James, 2010; Mattarolo, 1990). It might be seen interesting to increase food temperature to save energy (Anonymous), but because of accelerated product quality alteration caused by higher temperature (Duret et al., 2015; Duret, Guillier, Hoang, Flick, \& Laguerre, 2014), the global cost due to food waste or safety issues may increase (Zanoni \& Zavanella, 2012). Overemphasizing the importance of food safety could result in food waste and economic loss, whereas the opposite might cause serious health implications (Baranyi \& Buss da Silva, 2017; Guillier et al., 2016).

More recently, emerging concerns (e.g., climate change and the growing demand of consumers for sustainable foods) (Goodman, Maye, \& Holloway, 2010) lead governmental institutions and risk managers to include the sustainability assessment aspects in addition to food safety in food policy in order to evaluate global impact of an action (Anonymous, 2015; Mazzocchi, Ragona, \& Zanoli, 2013; Ruzante et al., 2010). For instance, potential evolution of food policy could be illustrated by the communication of the European Union and the member states for the prevention of food waste and losses, estimated at 88 million tons annually with an associated cost of 143 billion euros (Stenmarck, Jensen, Quested, \& Moates, 2016). Another example of the will to account for sustainability aspects of the food chain is the recent E.U.-funded project aiming to develop new innovative mathematical modeling tools that combine food quality and safety together with energy, environmental, and economic aspects to predict and control food quality and safety in the cold chain (Alvarez, 2015).

However, the inclusion of potentially conflicting objectives such as food safety, food waste, and energy consumption may be challenging because the comparison between the outcomes of those objectives (risk of illness, amount of food waste, energy consumption in $\mathrm{kWh}$ ) is a complicated task (Baranyi \& Buss da Silva, 2017; Guillier et al., 2016). Methodologies leading to overcome issues involving conflicting impacts and the knowledge of their limitations are essential to support decisionmakers. In this context, a risk-benefit assessment method (RBA), often used to account for positive and adverse effects of interventions, is not applicable because outcomes have to be comparable, and cost-benefit analysis (CBA) may be difficult to apply because cost data of the different outcomes are not always available. Multicriteria decision analysis (MCDA) was used to overcome issues involving conflicting and noncomparable outcomes in many fields (Adunlin, Diaby, Montero, \& Xiao, 2015; Angelis \& Kanavos, 2017; Humphries Choptiany \& Pelot, 2014; Linkov et al., 2006; Linkov et al., 2011; Yemshanov et al., 2013). MCDA is a formal mathematical approach that can be employed to integrate disparate, but important, criteria to inform decisions (Belton \& Stewart, 2002). This mathematical approach is particularly useful in situations in which no single a priori "optimal" solution exists and decisionmakers need to prioritize among diverse criteria to identify the "best compromise." Moreover, the flexibility of the approach and the possibility of facilitating the dialogue between stakeholders, analysts, and scientists were found to be useful in sustainability evaluation (Cinelli, Coles, \& Kirwan, 2014).

MCDA has been applied in many areas such as finance, ecology, drugs, and medical devices. MCDA 
has also been used in the food context as way to rank chemical or microbiological hazards (Fazil, Rajic, Sanchez, \& McEwen, 2008; Papadopoulos et al., 2015; Ruzante et al., 2010; Ruzante, Grieger, Woodward, Lambertini, \& Kowalcyk, 2017; U.S. Food and Drug Administration [FDA], 2015). In this context, MCDA has been used to combine several criteria related to incidence of adverse effects, their severity, and the consequences of risk on direct or indirect costs, or perception, by consumers (Anderson, Jaykus, Beaulieu, \& Dennis, 2011; FDA, 2015; Havelaar et al., 2010; Lake, Cressey, Campbell, \& Oakley, 2010; Ruzante et al., 2010). MCDA permitted in these situations to tackle all "negative" consequences of scenarios. Yet, as it has been recently suggested (Ruzante et al., 2017), the MCDA approach could be used to assess the risk and benefits of selected food safety interventions. MCDA appears as a solution in situations where the outputs of risk and benefit assessment are not expressed in a common unit.

This article proposes an original multidisciplinary approach linking prediction of product temperature in refrigeration processes, energy consumption, and predictive microbiology. More precisely, this study focuses on the cold chain of ham, including refrigerated transportation, storage in supermarket cold room, opened display cabinet, transport by consumer, and domestic refrigerator. It allows the evaluation of the impact of the intervention actions on three criteria. The three studied criteria are food safety, food waste, and environmental impact illustrated by the risk for human health associated with Listeria monocytogenes (L.m), product alteration due to the growth of lactic acid bacteria (LAB), and the energy consumption of the refrigerated equipment of the cold chain, respectively. A set of eight intervention actions were tested to quantitatively evaluate changes in the three criteria. Finally, the intervention actions were ranked using two MCDA methods (analytic hierarchy process and ELECTRE III) including decisionmakers' preferences (i.e., criteria weight). Results of the ranks given by the MCDA were compared with results obtained using a CBA of the actions.

\section{MATERIALS AND METHODS}

\subsection{Overview}

The objective of the model was the prediction of: (1) risk of listeriosis associated with the consumption of cooked ham; (2) food waste caused by the growth of spoilage organisms, included in this study with lactic acid bacteria (LAB), and (3) energy consumption of the refrigerated equipment of the cold chain to cool down and maintain product temperature. A discrete event framework was selected to describe the consecutive equipment of the cold chain. This framework allows the inclusion of additional events or the modification of event sequences. This flexibility facilitates the comparison between different food safety measures or intervention actions such as the implementation of new regulations in the risk assessment (Pouillot et al., 2015). A first-order Monte Carlo simulation was implemented to describe the variability of the cold chain logistic and the growth parameters of L.m and LAB.

The conceptual model is divided into four main modules (Fig. 1). The thermal module, described in Section 2.2, the core of the model, is based on the zonal approach. It allows the prediction of dynamic product time-temperature profiles from the product thermal properties, operating conditions (e.g., product position in equipment, thermostat setting, and ambient temperature) for the various equipment of the cold chain. Information on equipment design and operating conditions of the thermal module are used in the energy consumption module (Section 2.3) to calculate the energy required to cool down and maintain the product temperature in the equipment. The time-temperature profiles provided by the thermal module are also used in the predictive microbial models (Section 2.4) to estimate the growth of L.m and LAB. Biological variability of growth parameters is also considered, and detailed in Table I. Finally, the consumer module (Section 2.5) evaluates the number of illnesses and the disabilityadjusted life year (DALY) derived from consumer exposure to $L . m$ obtained by the predictive microbial module.

\subsection{Cold Chain Building}

Time-temperature profiles of products throughout the cold chain were modeled using a methodology combining thermal deterministic models to calculate product temperature in refrigeration equipment, and stochastic models to consider different sources of variability in the cold chain (sequence of the equipment, position, ambient conditions, and thermostat-setting temperature) (Flick, Hoang, Alvarez, \& Laguerre, 2012). The studied cold chain is presented in Fig. 2 and includes refrigerated 


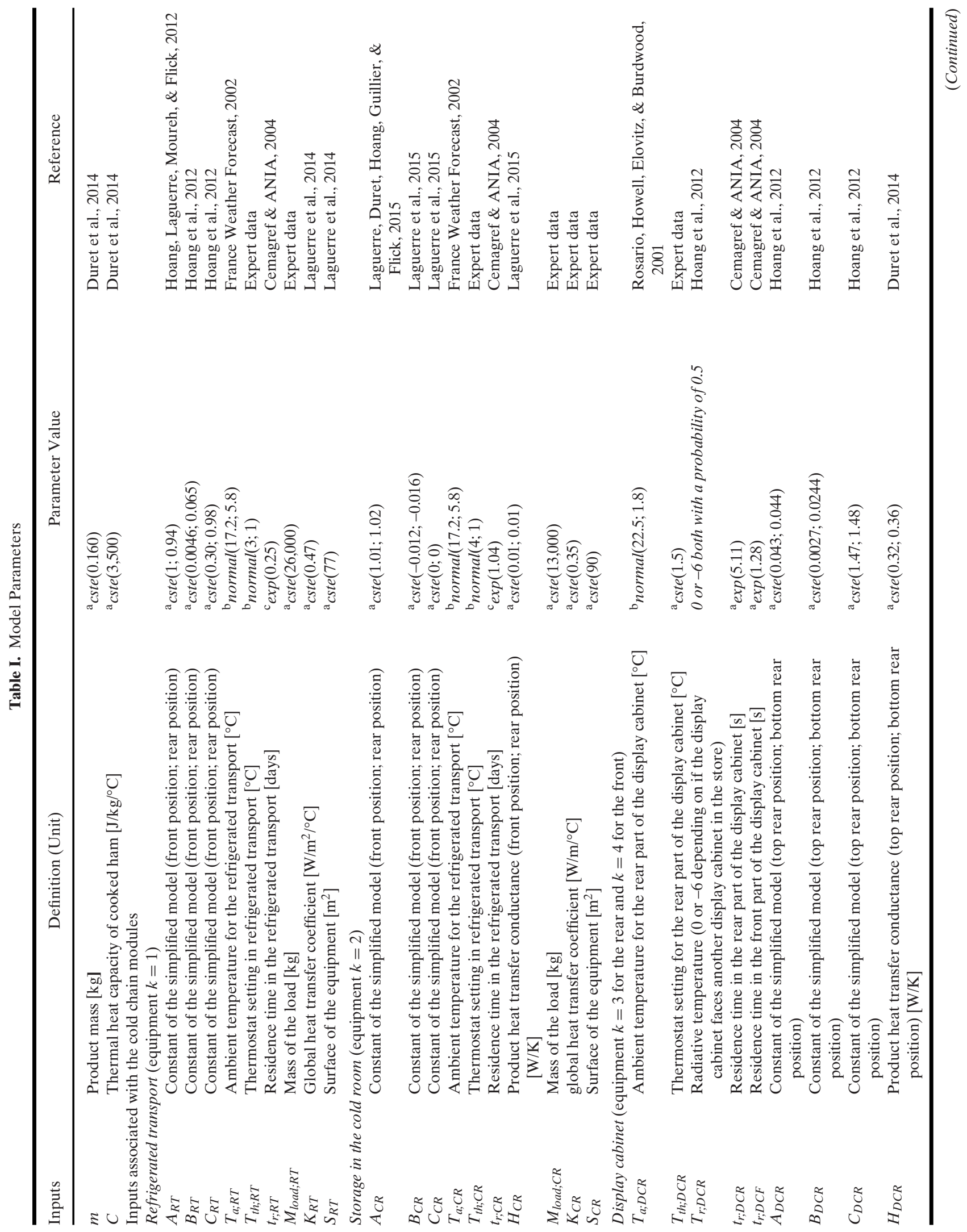




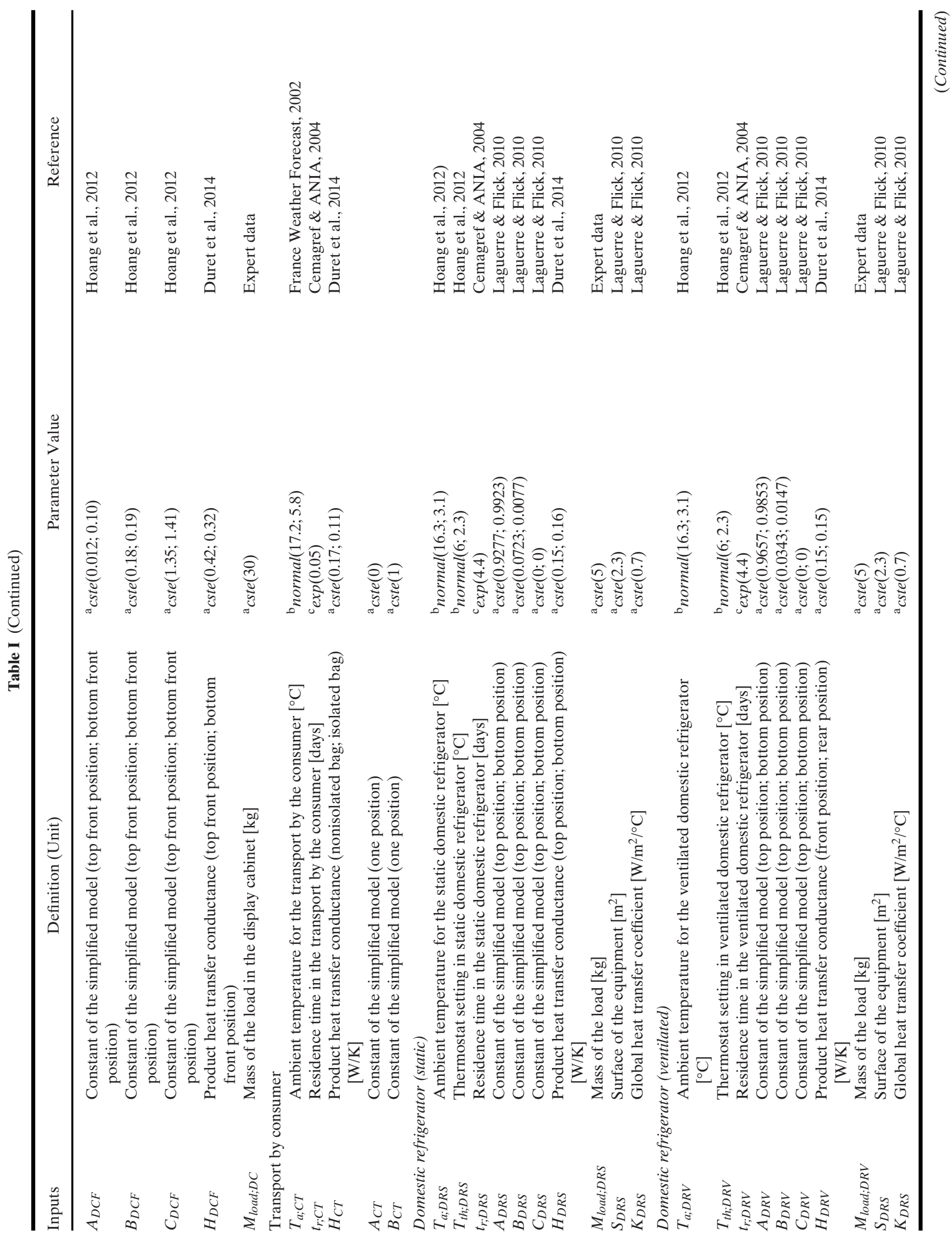


Duret et al.

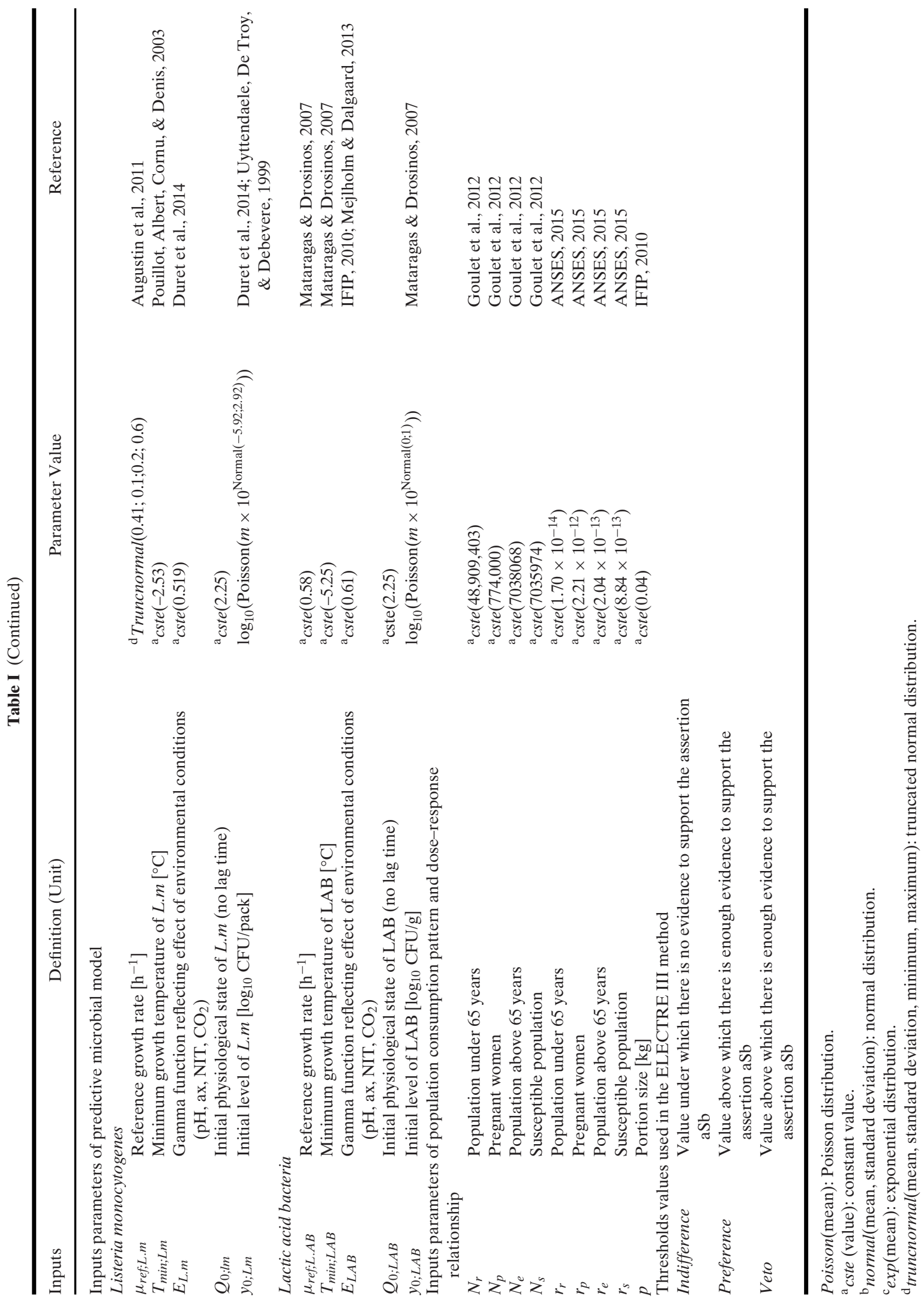




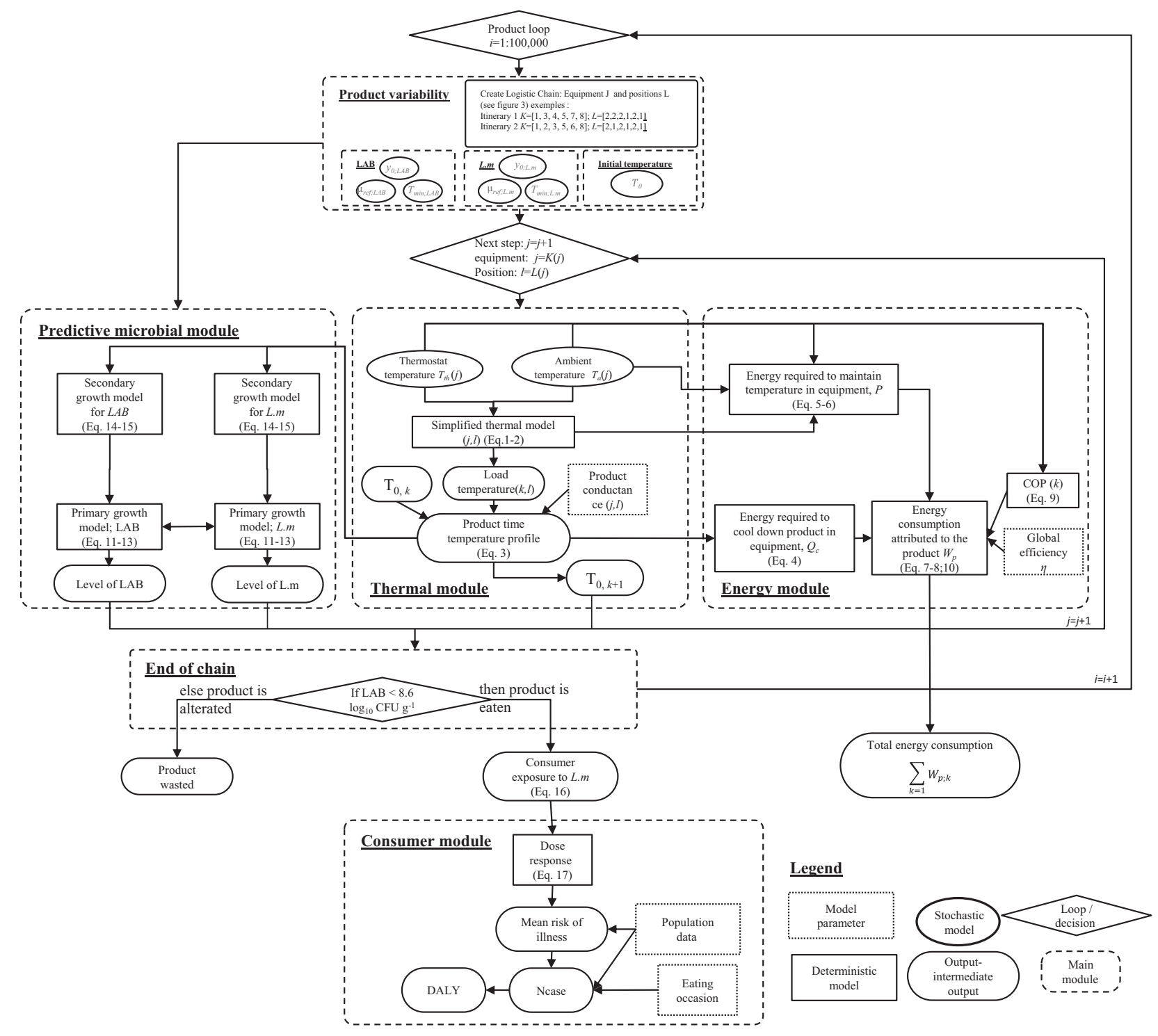

Fig. 1. Model overview.

transport (RT), storage in the supermarket cold room (CR), rear of the opened display cabinet (DCR), front of the opened display cabinet (DCF), transport by consumer, and two types of domestic refrigerators: a static refrigerator (DRS) and a ventilated refrigerator (DRV) with a probability of occurrence of 0.68 and 0.32 , respectively (Hoang, Flick, Derens, Alvarez, \& Laguerre, 2012). The display cabinet step was divided into two parts because most products were supposed to be placed firstly at the rear part before being moved to the front part. In this model, all chains start with the refrigerated transport, the following equipment is then determined according to a probability of transfer from piece of one equipment to another. For example, after the transport, the product has a probability of 0.2 to be placed in a cold room and 0.8 in the display cabinet ( 0.64 at the rear part and 0.16 at the front part). Because of a lack of data on the logistics, probabilities of product transfer from one link to another were based on expert opinion. In every piece of equipment, the product can be placed in two positions (top/bottom or rear/front) according to a probability of 0.5 , except in the transport by consumer, in which only one position was considered. 


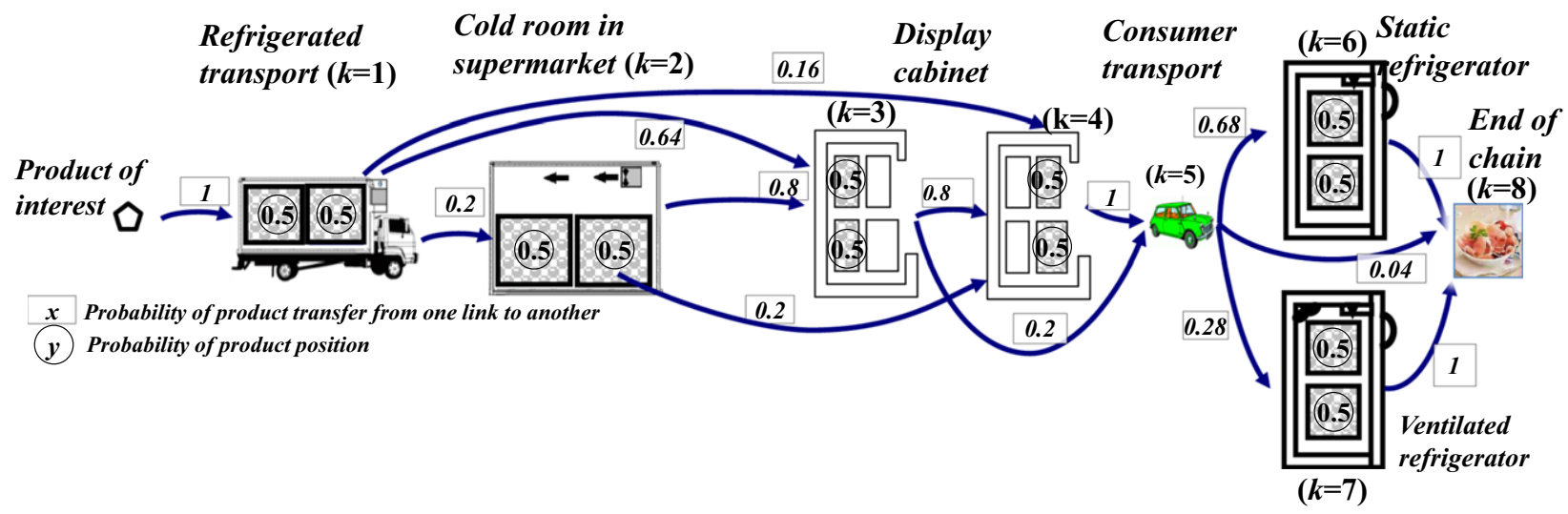

Fig. 2. Probability of the different itineraries of the product along the cold chain. Index $k$ indicates the equipment $(k=1$ : refrigerated transport, $k=2$ : cold room, $k=3$ : rear of the display cabinet, $k=4$ : front of the display cabinet, $k=5$ : consumer transport, $k=6$ : static refrigerator, $k=7$ : ventilated refrigerator, and $k=8$ : end of chain).

Products, called "product of interest," designated by index $i$, are independent and follow different itineraries because of the random nature of the logistic chain (type of equipment, position, residence time in the equipment, operating conditions). The steps of the product through the cold chain are indicated by the index $j$ whereas the types of equipment are indicated by the index $k$ (e.g., $k=$ 2 corresponds to the cold room; Fig. 3). Position in the equipment is defined by the index $l$. More details can be found in Duret et al. (2014). It is assumed that when the product of interest $i$ is placed in a piece of equipment, there are already other products (called load) in the equipment. The load temperature is time-independent. Once the product of interest $i$ is placed in a piece equipment $k$ at step $j$ and position $l$, its temperature $T_{i, j}(t)$ tends toward the load temperature $T_{l o a d, k, l}$. The temperature evolution $T_{i, j}(t)$ in a piece of equipment $k$ is calculated using:

$$
\begin{aligned}
T_{i, j}(t)= & T_{\text {load }, k, l}+\left(T_{o, i, j}-T_{\text {load }, k, l}\right) \\
& \times e^{\left(-H_{k, l} \times t\right) /(m \times C)}\left[{ }^{\circ} \mathrm{C}\right],
\end{aligned}
$$

where $t$ is the time, $T_{0, i, j}$ is the initial temperature of the product of interest $i$ at step $j$ when placed in the equipment $k$ at position $l$ (at $t=0), m$ is the mass of the product $(0.16 \mathrm{~kg}$ for a pack of four slices of cooked ham), $C$ is the heat capacity of the product $\left(3,500 \mathrm{~J} / \mathrm{kg} /{ }^{\circ} \mathrm{C}\right), H_{k, l i s}$ the heat transfer conductance of the product in equipment $k$, and position $l$. The load temperature of equipment $k$ (except the display cabinet) and position $l T_{\text {load }, k, l}$ is calculated from the operating conditions using zonal models developed

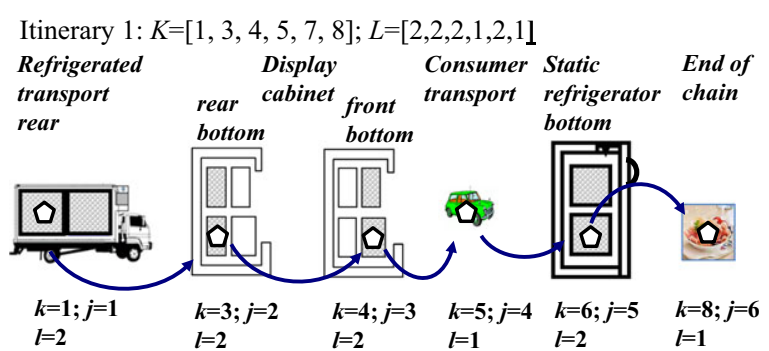

Itinerary $2: K=[1,2,3,5,8] ; L=[2,1,2,1,1]$

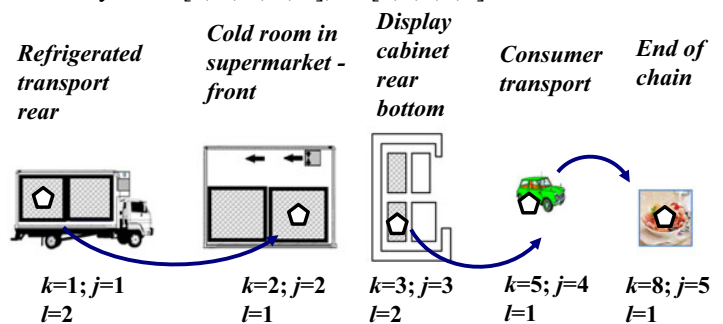

Fig. 3. Examples of itineraries of the logistic chain. Index $k$ indicates the equipment $(k=1$ : refrigerated transport, $k=2$ : cold room, $k=3$ : rear of the display cabinet, $k=4$ : front of the display cabinet, $k=5$ : consumer transport, $k=6$ : static refrigerator, $k=$ 7: ventilated refrigerator, $k=8$ : end of chain), index $j$ indicates the step, index $l$ the position ( $l=1$ : front or top, $l=2$ : rear or bottom). The product of interest is represented by the hexagon.

in previous research (Laguerre, Duret, Hoang, \& Flick, 2014):

$$
T_{\text {load }, k, l}=A_{k, l} \times T_{t h, k}+B_{k, l} \times T_{a, k}+C_{k, l}\left[{ }^{\circ} \mathrm{C}\right],
$$

where $T_{t h, k}$ is the thermostat temperature of the equipment $k, T_{a, k}$ is the ambient temperature (e.g., air temperature in the kitchen for the domestic refrigerator); the thermostat and ambient 
temperatures are independent of the position because those parameters are operating conditions of the whole equipment. $A_{k, l}, B_{k, l}$, and $C_{k, l}$ are constants of the simplified models and are dependent of the position. Distributions and values for the model parameters are detailed in Table I.

For the display cabinet, due to the nonnegligible effect of the radiative temperature (related to the wall temperature in front of the display cabinet), the load temperature is calculated with:

$$
T_{\text {load }, k, l}=A_{k, l} \times T_{t h, k}+B_{k, l} \times T_{a, k}+C_{k, l} \times T_{r, k}\left[{ }^{\circ} \mathrm{C}\right],
$$

with $T_{r, k}$ the radiative temperature given in Table I.

\subsection{Modeling the Energy Consumption of Refrigerated Equipment}

The energy required for the refrigeration of food products throughout the cold chain was calculated for each product from the operating conditions and equipment design (i.e., static/ventilated refrigerators). Only the energy involved for the refrigeration was taken into account; for example, the fuel consumption in the refrigerated transport or the energy of the fans in the cold room were not included in the model. The energy required for product cooling was calculated using:

$$
Q_{c}=m \times C \times\left(T_{0}-T_{\text {end }}\right)[\mathrm{J}],
$$

with $m$ the product mass, $C$ the product heat capacity, and $T_{0}$ and $T_{\text {end }}$ the product temperature when placed and removed from the equipment, respectively.

The refrigerating power required to maintain the temperature inside the equipment due to the heat transfer through the walls of the equipment was calculated with:

$$
P=K \times S \times\left(T_{a}-T_{t h}\right)[\mathrm{W}],
$$

with $K$ the global heat transfer coefficient of the equipment $\left[\mathrm{W} / \mathrm{m}^{2} /{ }^{\circ} \mathrm{C}\right], S$ the surface area of the equipment $\left(\mathrm{m}^{2}\right)$, and $T_{a}$ and $T_{t h}$ the ambient and thermostat temperatures, respectively.

For the display cabinet, the refrigerating power is calculated differently using the air mass flow rate $\left(\dot{m}_{a i r}\right)$ of the curtain and the temperatures of discharge air at inlet and return air at outlet ( $T_{a i r ; I}$ and $\left.T_{a i r ; O}\right)$ obtained with the simplified zonal model:

$$
P=\dot{m}_{\text {air }} \times C_{\text {air }} \times\left(T_{\text {air } ; O}-T_{\text {air } ; I}\right)[\mathrm{W}] .
$$

Electrical consumption of the equipment considering both the energy required to cool down and to maintain product temperature was calculated using Equations (7) and (8), respectively:

$$
\begin{aligned}
W_{c} & =\frac{Q_{c}}{\eta \times C O P}[\mathrm{~J}], \\
W_{e} & =\frac{\frac{m}{M_{\text {load }}} P \times t}{\eta \times C O P}[\mathrm{~J}],
\end{aligned}
$$

with $m$ the product mass $(0.16 \mathrm{~kg})$ and $M$ the total mass of food products in the equipment (Table I), $\eta$ the global performance coefficient of the cooling unit ( $\eta$ is considered to be 0.5), and COP the coefficient of performance of Carnot, corresponding to the ratio of the useful cooling provided to the work required (not including thermodynamic irreversibility in the refrigerating machine), calculated with:

$$
C O P=\frac{T_{\text {cold }}}{T_{\text {hot }}-T_{\text {cold }}},
$$

with $T_{\text {cold }}$ and $T_{\text {hot }}$ the temperatures of the cold and hot sources (refrigerant in the heat exchangers), respectively, estimated from the thermostat temperature $\left(T_{t h}\right)$ and the ambient temperature $\left(T_{a}\right)$ and using a temperature pinch of $10{ }^{\circ} \mathrm{C}$ (temperature difference between the air and the refrigerant in the heat exchanger) (i.e., $T_{\text {cold }}=T_{t h}-10$ and $T_{h o t}=T_{a}$ $+10)$. The air temperature at the evaporator was assumed equal to the thermostat temperature $T_{t h}$.

Finally, the energy attributed to the product in the equipment was calculated using:

$$
W_{p}=W_{e}+W_{c}[\mathrm{~J}] .
$$

\subsection{Predictive Microbiology Models}

\subsubsection{Growth}

Both the growth of L.m and LAB in cooked ham were predicted using the same procedure. The Barany and Robert's primary growth model (Equations (11) and (12)) (Baranyi \& Roberts, 1994), in which lag time is modeled through the evolution of the physiological state $Q(t)$ (Equation (12)) and including growth competition Jameson effect (simultaneous deceleration of all microbial populations), was used to predict the growth of L.m and $\mathrm{LAB}$ over time:

$$
\begin{aligned}
\frac{d y(t)}{d t}= & \frac{1}{1+e^{-Q(t)}} \times \mu_{\max } \times\left(1-e^{y_{L, m}-y_{\max , L, m}}\right) \\
& \left(1-e^{y_{L A B}-y_{\max , L A B}}\right),
\end{aligned}
$$




$$
\begin{gathered}
\frac{d Q(t)}{d t}=\mu_{\text {max }}(T) \times E, \\
y(0)=y_{0} \text { and } Q(0)=Q_{0},
\end{gathered}
$$

where $y(t)\left(\log _{10} \mathrm{CFU} /\right.$ pack $)$ is the bacteria population, $y_{\max }$ the maximum population $\left(9 \log _{10} \mathrm{CFU} / \mathrm{g}\right)$, $Q$ the physiological state, $\mu_{\max }$ the maximum growth rate, $T$ the product temperature, $E$ the effect of the physicochemical properties of the product, $y_{0}$ the initial level, and $Q_{0}$ the initial physiological state. Values and distribution of these parameters are given in Table I.

Secondary growth models based on the gamma concept were used to describe the effect of the environment on the growth of LAB and L.m (Mejlholm \& Dalgaard, 2013; Mejlholm et al., 2010). The effect of temperature, water activity, $\mathrm{pH}$, nitrite, and $\mathrm{CO}_{2}$ concentration were considered but interactions between those variables were neglected. The values of these product properties were obtained from a survey including 50 packs of cooked ham from 10 different brands (Institut du porc [IFIP], 2010):

$$
\begin{gathered}
\mu_{\text {max }}=\mu_{\text {ref }} \times\left(\frac{T-T_{\text {min }}}{T_{\text {ref }}-T_{\text {min }}}\right)^{2} \times E, \\
E=\left(\frac{a w-a w_{\min }}{1-a w_{\min }}\right) \times\left(1-10^{p H_{\min }-p H}\right) \\
\times\left(\frac{N I T_{\max }-N I T}{N I T_{\max }}\right)^{2} \times\left(\frac{C O_{2 ; \text { max }}-C O_{2 ; \text { Equilibrium }}}{C O_{2 ; \text { max }}}\right),
\end{gathered}
$$

where $\mu_{r e f}$ is the reference growth rate, $T_{r e f}$ the reference temperature, $a w$ is the water activity, and NIT and $\mathrm{CO}_{2 \text { equilibrium }}$ are the concentrations ( $\mathrm{ppm}$ ) of nitrite and the dissolved $\mathrm{CO}_{2}$ at equilibrium, respectively. $T_{\min }, a w_{\min }, p H_{\min }, N I T_{\max }$, and $\mathrm{CO}_{2 \max }$ are the theoretical minimal value of temperature, water activity and $\mathrm{pH}$, and the maximal concentrations (ppm) of nitrite and $\mathrm{CO}_{2}$. The values of the model parameters are presented in Table I.

\subsection{Consumption, Consumer Exposure, Dose Response, and Risk Characterization}

Products with a level of LAB $>8.6 \log _{10} \mathrm{CFU} / \mathrm{g}$ were considered altered and assumed to not be consumed (Mataragas, Drosinos, Vaidanis, \& Metaxopoulos, 2006). The consumption pattern of cooked ham of the French population was assumed to be similar to the consumption pattern of cooked meat in Europe with 114.4 and 146.25 eating occasions for population under 65 years and population over 65 years, respectively (European Food Safety Authority [EFSA], 2018). The portion size $p$ per eating occasion was $0.40 \mathrm{~kg}$, according to the literature (French Agency for Food, Environmental and Occupational Health \& Safety [ANSES], 2017), and corresponding to one cooked ham slice of the pack (four slices in a pack of $0.16 \mathrm{~kg}$ ). This assumption is in agreement with the data of the EFSA consumption database for the category of ready-to-eat products (EFSA, 2018). For each eating occasion, the amount of ingested L.m $\left(N_{\text {ing }}\right)$, assuming that the contamination was uniformly distributed in the pack, was calculated with:

$$
N_{\text {ing }}=\frac{p}{m} 10^{y_{\text {end }},}
$$

with $p$ the portion size $(0.04 \mathrm{~kg}), m$ the product mass (four slices of $0.04 \mathrm{~kg}$ in a pack of $0.16 \mathrm{~kg}$ ), and $y_{\text {end }}$ the concentration of L.m $\left(\log _{10} \mathrm{CFU} / \mathrm{g}\right)$ at the time of consumption. A L.m exponential dose-response model was used to evaluate the risk of illness resulting from the consumption of cooked ham in the population (Pouillot, Goulet, Delignette-Muller, Mahe, \& Cornu, 2009):

$$
R\left(i l l \mid N_{\text {ing }}\right)=1-\exp \left(-r \times N_{\text {ing }}\right),
$$

with $r$ the probability of developing invasive listeriosis from the ingestion of one bacteria cell; $r$ was assumed to be independent to the ingested dose and independent of the strains. Four population groups were considered: population under 65 years, population over 65 years, pregnant women, and susceptible population. The population size and the probability of developing invasive listeriosis are given in Table I.

The disability-adjusted life year (DALY) template was used to characterize the risk. Values from literature of 1.14 and 9.19 DALY per case were used for the adult and perinatal forms of listeriosis, respectively (ANSES, 2015; Havelaar et al., 2012).

\subsection{Baseline and Action Measures}

A set of eight intervention actions, described in Table II, were studied. Action 1, the baseline of this study, represents the existing knowledge of the current cold chain logistic and operating conditions. Only one parameter was changed in the other actions to evaluate their impact. For example, domestic refrigerator average setting temperature was evaluated 
Table II. Description of the Actions and Values of the Model Modified Parameters

\begin{tabular}{|c|c|c|}
\hline Actions & $\begin{array}{l}\text { Parameter Value in the } \\
\text { Standard Scenario }\end{array}$ & New Parameter Value \\
\hline \multicolumn{3}{|l|}{ 1: Standard, current cold chain operating conditions } \\
\hline 2: Domestic refrigerator thermostat setting at $4{ }^{\circ} \mathrm{C}$ & $T_{t h} \sim N(6 ; 2.3)$ & $T_{t h} \sim N(4 ; 2.3)$ \\
\hline 3: Domestic refrigerator thermostat setting at $7^{\circ} \mathrm{C}$ & $T_{t h} \sim N(6 ; 2.3)$ & $T_{t h} \sim N(7 ; 2.3)$ \\
\hline 4: More performance refrigerator: better thermal insulation & $K=0.7 \mathrm{~W} / \mathrm{m}^{2} /{ }^{\circ} \mathrm{C}$ & $K=0.3 \mathrm{~W} / \mathrm{m}^{2} /{ }^{\circ} \mathrm{C}$ \\
\hline 5: Decrease of air curtain flow rate in the display cabinet $(50 \%)$ & $\dot{m}_{\text {air }}=0.09 \mathrm{~kg} / \mathrm{s}$ & $\dot{m}_{\text {air }}=0.045 \mathrm{~kg} / \mathrm{s}$ \\
\hline 6: Decrease of air curtain flow rate in the display cabinet $(75 \%)$ & $\dot{m}_{\text {air }}=0.09 \mathrm{~kg} / \mathrm{s}$ & $\dot{m}_{\text {air }}=0.068 \mathrm{~kg} / \mathrm{s}$ \\
\hline 7: Increase of air curtain flow rate in the display cabinet $(125 \%)$ & $\dot{m}_{\text {air }}=0.09 \mathrm{~kg} / \mathrm{s}$ & $\dot{m}_{\text {air }}=0.113 \mathrm{~kg} / \mathrm{s}$ \\
\hline 8: Thermostat setting of the display cabinet $=2.5^{\circ} \mathrm{C}$ & $T_{t h}=1.5^{\circ} \mathrm{C}$ & $T_{t h}=2.5^{\circ} \mathrm{C}$ \\
\hline
\end{tabular}

in actions 2 and 3 in which the average setting of the thermostat was set to $4{ }^{\circ} \mathrm{C}$ and $7{ }^{\circ} \mathrm{C}$, respectively, instead of $6^{\circ} \mathrm{C}$ in the baseline. The impact of a better insulation of the domestic refrigerator was evaluated in action 4. The impact of the airflow rate in the air curtain of the display cabinet was tested in actions 5, 6 , and 7. Finally, the impact of the thermostat setting modification of the display cabinet was evaluated in action 8.

\subsection{Action Ranking Methodologies}

The ranking of the eight actions was conducted by evaluating the annual global cost of the actions, and using two multicriteria decision analysis (MCDA) methodologies: ELECTRE III and analytical hierarchy process (AHP).

\subsubsection{Cost-Benefit Analysis (CBA)}

The costs of the three criteria were estimated based on literature data in order to evaluate the annual global cost of each action: $€ 100,000 / D A L Y$ (ANSES, 2015; Mangen, Havelaar, Poppe, \& de Wit, 2007 ), $€ 15.29 / \mathrm{kg}$ of food wasted (Institut National de la Statistique et des Etudes Economiques [INSEE], 2018 ), and $€ 0.0957 / \mathrm{kWh}$ for the refrigerated transport, the cold room, and the display cabinet, and $€ 0.14 / \mathrm{kWh}$ for the domestic refrigerator of electricity (Anonymous, 2018).

\subsubsection{Multicriteria Decision Analysis Methods}

Two of the most common MCDA methods were used and compared in this study and are briefly described in the following subsections. Further details can be found in Greco, Ehrgott, and Figueira (2016).
2.7.2.1. Analytical hierarchy process (AHP). The analytical hierarchy process (AHP) is a performance aggregation based approach introduced by Saaty (1980). AHP is a value measurement model (VMM). Value measurement models aim at assigning a real number or value to the alternatives and therefore providing a rank or preference order. AHP aims at evaluating tangible and nontangible criteria in relative terms by means of an absolute scale. The first step of the process requires the identification of a set of actions and a hierarchy of evaluation criteria (value tree). The action ranking is performed by pairwise comparisons of the actions' performance on criteria (scoring) and criteria among themselves (weighting) (Belton \& Stewart, 2002). The action scores and criteria weight are used to evaluate the overall performance of each action by means of a linear additive model (Saaty, 2005). Final score is a value between 0 and 1 with 0 the best score and 1 the worst score. However, in this study, in order to facilitate the comparison with the ELECTRE III method (Roy, 1991), final scale was reversed (1-Score) with 1 the best score and 0 the worst.

2.7.2.2. ELECTRE III. ELECTRE (ELimination and Choice Expressing Reality) are preference aggregation based methods. Proposed by Roy (1991), ELECTRE methods are also defined as outranking methods in the sense that the approach consists in assessing whether an action $a$ is at least as good as action $b$ ( $a$ outranks $b ; a S b$ ) (Belton \& Stewart, 2002; Cinelli et al., 2014). Outranking methods typically consist of making pairwise comparison of alternatives on each criterion, which, in turn, are then combined to obtain a measure of support for each alternative being judged the top-ranked alternative overall. Several ELECTRE 
Duret et al.

methods were developed over the last decades to solve various decision problems. In this study, the ELECTRE III method was used (Roy, 1978). To validate an outranking relation of an action $a$ over an action $b$, the two following concepts must be fulfilled (Figueira, Mousseau, \& Roy, 2016): (1) a sufficient majority of criteria should be in favor of this assertion (concordance) and (2) when the concordance condition holds, none of the criteria in the minority should oppose too strongly to the assertion $a S b$ (nondiscordance). Three threshold values must be determined for each criterion to implement the method: indifference, preference, and veto. In this study, for each criterion, the indifference threshold value of criteria corresponds to $5 \%$ of the average value of all actions on the criteria, meaning that if the difference between the two actions is below the indifference threshold, there is no evidence to support the assertion $a S b$. For the preference and veto thresholds, values of $10 \%$ and $40 \%$ of the average value of all actions were used, respectively. Although in this, those values were set for the example, they are usually determined along with the risk managers. The ELECTRE III method was chosen in this study because of its possibility, through the veto threshold, to penalize an action when its adverse effect on one or several criteria is too important. This possibility may be useful in food policy, for example, when risk managers want to mitigate adverse effect of the actions on human health.

\subsubsection{Weighing of Criteria}

One of the difficult tasks in MCDA is determining the weights of each criteria. The weights are usually obtained by asking decisionmakers (DM) their preferences on a scale from 1 (no preference) to 9 (absolute preference). Three scenarios were studied. In the first scenario, no preference was set, all the criteria have the same weight (i.e., all weights are equal to 1 ). In the scenario \#2, preference was given to food safety (i.e., weight of 9 for food safety, 1 for food waste and energy consumption) whereas in scenario \#3, preference was attributed to energy consumption (i.e., weight of 9 for energy consumption, 1 for food safety and food waste). In addition to the three scenarios, a set of 10,000 scenarios with random weights ranging from 1 to 9 were simulated to evaluate the sensitivity of the MCDA methods to the choice of the weight.

\subsection{Implementation of the Model}

The AHP approach (Section 2.7.2.1) was written in the open-source language $\mathrm{R}$ version 3.3.3 (R Core Team), using the $\mathrm{R}$ package "MCDA" (Meyer, Bigaret, Hodgett, \& Olteanu, 2018). All the other functions of the model used in this study (including ELECTRE III method) were implemented in the Matlab software R2016b (MathWorks Inc., Natick, MA, USA). For each action tested, 100,000 time-temperature profiles were simulated. For each time-temperature profile, 100 independent products following the same itinerary but with different biological parameters (e.g., initial population of L. $m$ and $\mathrm{LAB}$, growth rates, minimum temperature of growth) were considered, resulting in a total of $10^{7}$ iterations. The convergence of the mean risk of illness, the more sensitive output of the model due to the nature of the dose-response model of L.m, was verified graphically (result not shown). The code of the model and the code used for the MCDA are available on request to the corresponding author.

\section{RESULTS}

\subsection{Influence of Actions on Health Risk, Product Waste, and Energy Consumption}

The results of the intervention actions (proportion of eaten products with a level of L.m exceeding $100 \mathrm{CFU} / \mathrm{g}$, annual number of listeriosis cases, annual number of DALYs, proportion of wasted products, and electrical consumption per pack) are shown in Table III. For a total number of 6.84 $\times 10^{9}$ servings, the expected annual numbers of listeriosis cases in the baseline (action 1) for the four population groups-population under 65 years, population over 65 years, pregnant women, and susceptible population-are $0.2,0.4,0.4$, and 1.5, respectively, for total annual number of cases of 2.5. The associated DALY is 6.09 years lost. The proportion of wasted products $\left(\mathrm{LAB}>8.6 \log _{10} \mathrm{CFU} / \mathrm{g}\right)$ is $7.74 \%$ and the average consumption of electricity of $0.044 \mathrm{kWh} /$ pack. In action 2, in which the average thermostat temperature of the domestic refrigerator was set at $4{ }^{\circ} \mathrm{C}$, the number of cases, the DALY, and the proportion of wasted products are the lowest compared to the other actions with respective values of 0.8 cases, 1.94 years, and $3.92 \%$. The energy consumption increased to $0.048 \mathrm{kWh} /$ pack. The opposite phenomena was observed in action 3, in which the average thermostat temperature of the domestic 


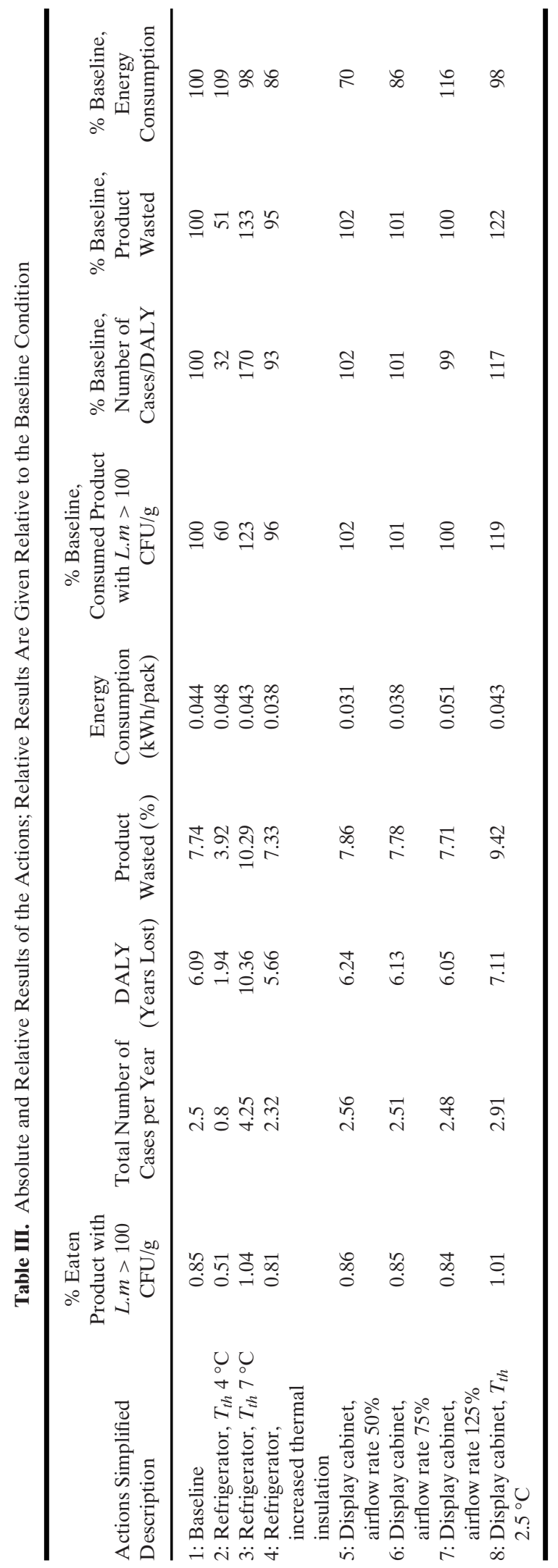

refrigerator was set at $7{ }^{\circ} \mathrm{C}$. Action 4 (increased thermal insulation of the domestic refrigerator) was the only one for which all criteria decreased. The DALY, the proportion of wasted products, and energy consumption were 5.66 years, $7.33 \%$, and 0.038 . The reduction of the airflow rate in the display cabinet by $25 \%$ (action 6) increased health risk and food waste by $1 \%$ and reduced energy consumption by $14 \%$. Increasing the airflow rate by $25 \%$ increased energy consumption by $16 \%$ without changes in the proportion of wasted products and decreasing the DALY by $1 \%$.

\subsection{Cost of the Alternative Actions}

The costs related to the DALY, food waste, energy consumption, and the total cost are presented in Table IV. In all actions, the higher part of the cost is related to food waste, followed by the cost of the energy consumption and by the cost associated with the DALY. Action 2 gives the minimal total cost (M€179) in which the thermostat of the domestic refrigerator is set at an average of $4{ }^{\circ} \mathrm{C}\left(6{ }^{\circ} \mathrm{C}\right.$ in the reference action). Action 3 (the thermostat of the domestic refrigerator was set at $7{ }^{\circ} \mathrm{C}$ ) gives the highest cost (M€488).

\subsection{Alternative Action Rankings of the MCDA}

Fig. 4 presents the scores of the actions for the two MCDA methodologies given three scenarios: no preference (scenario \#1), preference for food safety (scenario \#2), and preference for energy conservation (scenario \#3). The ranking of the actions by the two MCDA methods for the three scenarios are slightly different. In scenarios \#1 and \#2, the action presenting the "best compromise" for the two MCDA methods is action 2, followed by action 5 for the ELECTRE III method and by actions 4 and 5 for the AHP method. In scenario \#3 (preference for energy conservation), the best action for the two methodologies is action 5: reduction of the airflow by $50 \%$ in the display cabinet.

Fig. 5 shows the scores of the actions given 1,000 scenarios of criteria weights randomly sampled between 1 and 9 for each scenario to illustrate the impact of the criteria weight. The scale of the ELECTRE III varies from -8 to 8 , whereas the scale of the AHP varies from 0 to 1 . However, in both methods, a higher score represents the better action. In spite of the difference of score values, ranking results between the two methods are similar. Action 2 presents 
Table IV. Annual Cost (in Million $€$ )

\begin{tabular}{|c|c|c|c|c|c|}
\hline Actions Simplified Description & DALY & $\begin{array}{l}\text { Product } \\
\text { Wasted }\end{array}$ & $\begin{array}{l}\text { Electrical Energy } \\
\text { Consumption }\end{array}$ & Total Cost & $\begin{array}{c}\% \text { Reference Total } \\
\text { Cost (Rank) }\end{array}$ \\
\hline 1: Baseline & 0.61 & 350 & 8.19 & 359 & $100(3)$ \\
\hline 2: Refrigerator, $T_{t h} 4^{\circ} \mathrm{C}$ & 0.19 & 170 & 8.96 & 179 & $50(1)$ \\
\hline 3: Refrigerator, $T_{t h} 7^{\circ} \mathrm{C}$ & 1.04 & 479 & 7.83 & 488 & $136(8)$ \\
\hline 4: Refrigerator, increased thermal insulation & 0.57 & 330 & 6.75 & 337 & $94(2)$ \\
\hline 5: Display cabinet, airflow rate $50 \%$ & 0.62 & 356 & 5.98 & 363 & $101(6)$ \\
\hline 6: Display cabinet, airflow rate $75 \%$ & 0.61 & 352 & 7.08 & 360 & $100(3)$ \\
\hline 7: Display cabinet, airflow rate $125 \%$ & 0.61 & 349 & 9.29 & 359 & $100(3)$ \\
\hline 8: Display cabinet, $T_{t h} 2.5^{\circ} \mathrm{C}$ & 0.71 & 434 & 7.90 & 443 & $123(7)$ \\
\hline
\end{tabular}

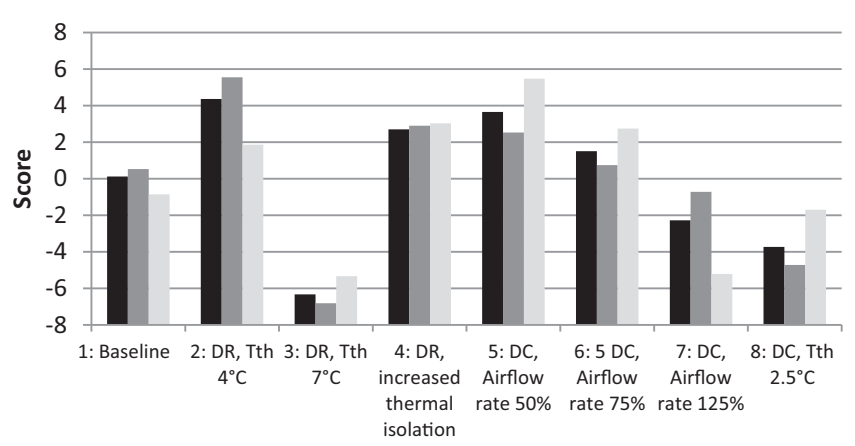

(a)

Scenario 1:

No preference

- Scenario 2:

Preference for food

safety

Scenario 3:

Preference for energy

preservation

isolation

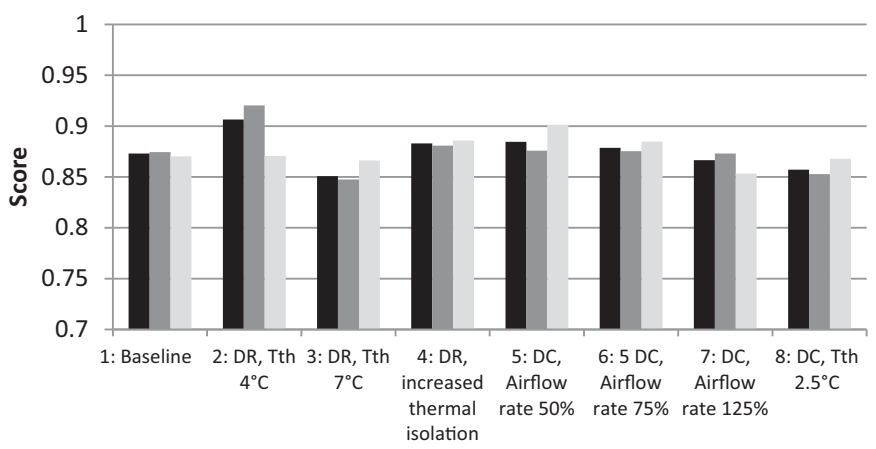

(b)

Scenario 1: No preference

- Scenario 2:

Preference for food

safety

Scenario 3:

Preference for energy

preservation

Fig. 4. Scores (rank) of the alternatives for the ELECTRE III (a) and AHP (b) for three scenarios. Scenario 1: no preference, scenario 2: preference for food safety, and scenario 3: preference for energy conservation.

the highest scores for most of the weight scenarios whereas action 3 presents the lowest scores.

\section{DISCUSSION}

\subsection{Analysis of Model Limitations}

The food cold chain is facing many challenges related to, for example, logistics and public awareness and may not be operated in optimal state. Because of potentially conflicting criteria (i.e., food safety, food waste, energy consumption), it may be difficult to measure the relative or the combined impacts of different actions. A solution would be to conduct a large-scale field experiment, following food products from production to consumption, and reporting cold chain operating conditions. Such experiments would offer a better understanding of the actions' impact and could also be useful for model validation. However, limitations due to feasibility, ethics, and costs put this solution out of consideration (Duret et al., 2017). Predictive models offer an alternative solution in this situation and can provide a good insight and help decisionmakers to determine the action presenting the best compromise. In risk assessment and 

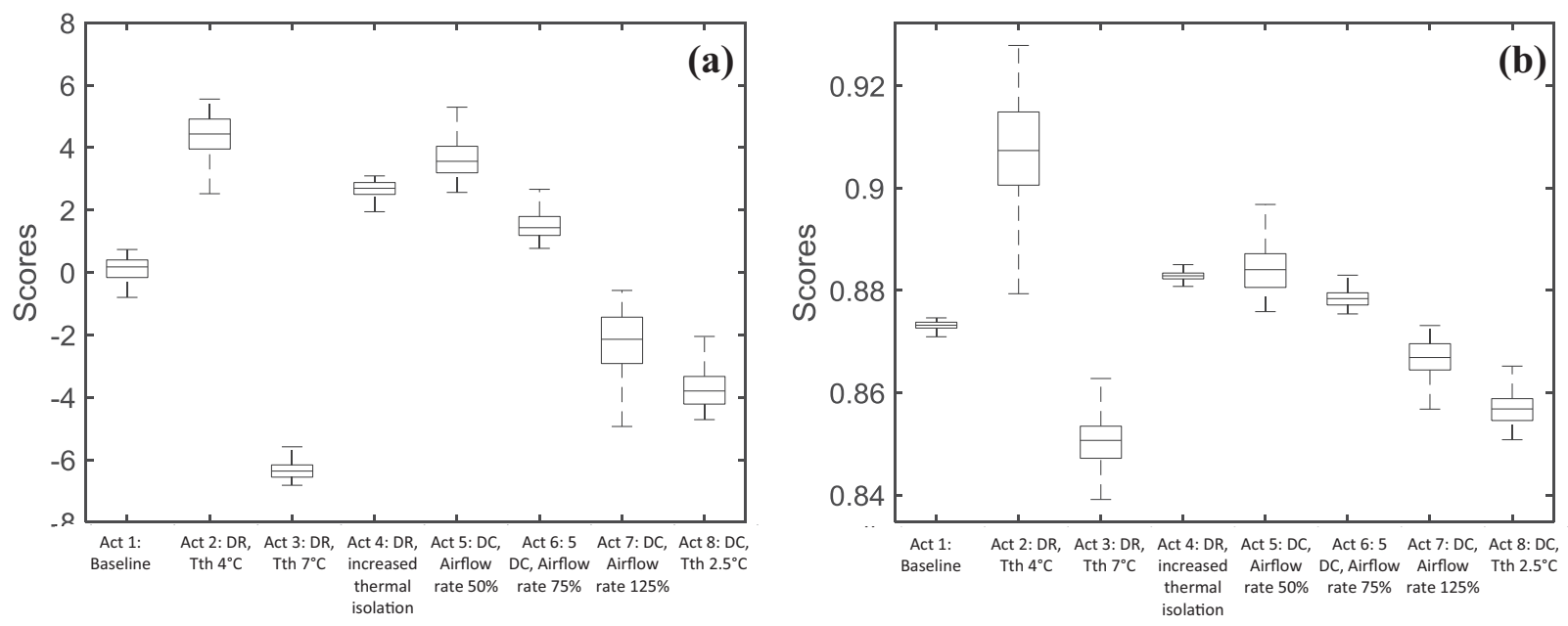

Fig. 5. Scores of the actions for 1,000 scenarios of criteria weights randomly sampled between 1 and 9. (a) ELECTRE III and (b) AHP.

model prediction in general, limitations are mainly related to included data and assumptions. The model developer has to ensure that results are driven by validated models and robust literature data. In this study, validated and published simplified zonal models to predict product temperature in the equipment and predictive microbial models were used; data were obtained from extensive literature review (Table I). The number of cases for the evaluation of the risk characterization of $L . m$ was obtained using an exponential dose-response model. As the majority of cases of listeriosis appear to be sporadic, and reported outbreaks are usually small, the links between cases and food at the origin of the illness are difficult and the accuracy of the dose-response models of L. $m$ regarding the strain virulence and host susceptibility is still debated (EFSA, 2018; Pouillot, Hoelzer, Chen, \& Dennis, 2015). Four groups were used to describe the variability of the host susceptibility. As an alternative output, the proportion of products eaten with a level of $L . m>100 \mathrm{CFU} / \mathrm{g}$ was provided.

A major data gap of this model is the level of spoilage bacteria for which product is assumed altered, not eaten by the consumer, and considered in this study as wasted. This data gap is major as it affects risk and food waste. This level has a high impact because the mean risk of illness calculated using an L.m dose-response model (Equation (17)) is highly sensitive to high levels of L.m in foods (Pouillot \& Lubran, 2011). High levels of $L . m$ are present in food products subjected to temperature abuse through the cold chain, leading also to high levels of LAB and potentially altered products. The impact of this parame- ter, set to $8.6 \log _{10} \mathrm{CFU} / \mathrm{g}$ in the model, was evaluated in two additional simulations in which the level of alteration was set to 8.3 and $8.9 \log _{10} \mathrm{CFU} / \mathrm{g}$ (Mataragas et al., 2006). Results show a number of listeriosis cases ranging from 1.59 to 5.52 cases, corresponding to a DALY ranging from 3.87 to 13.46 years lost, and a number of wasted products of 8.94 and $5.99 \%$, respectively. The total cost for levels of alteration of 8.3 and $8.9 \log _{10} \mathrm{CFU} / \mathrm{g}$ were 417 and $266 \mathrm{M} €$, respectively. Finally, based on this method, the total cost is mainly impacted by the cost associated with the number of wasted products. However, the cost of food waste might be overestimated. This cost corresponds to the retail price (money spent by the consumer). In fact, various benefits (made by the distributor, the supplier, or other stakeholders) that could reduce the cost of food waste were not included. On the other hand, waste treatment cost, which would increase the cost of food waste, was not included either.

The model of this study represents the real cold chain of cooked ham in France in the sense that existing knowledge and available data from the literature were used. The results of this study may vary in the absolute scale compared to what could be expected in reality, but the relative impact between the actions and the conclusions are expected to be robust and generalizable. First links of the chain (factory, distribution warehouse), other types of equipment (e.g., closed display cabinet), cold chain breach (except transport by consumer), door openings, product contamination in the domestic refrigerator after opening, or compliance with proposed actions were not included in this study. However, those 
features may easily be integrated in the discrete event framework, to the extent that data are available.

\subsection{Result Analysis}

\subsubsection{Results of the Alternative Actions on Different Criteria}

Although European consumers place the responsibility of maintaining the cold chain on the food suppliers and retailers (Ovca \& Jevsnik, 2009), results of this study show that the thermostat setting of the domestic refrigerator appears to have a high impact on food safety and food waste criteria and confirm results found in a previous study (Duret et al., 2014). For example, a reduction of the average by $2{ }^{\circ} \mathrm{C}$ would reduce by $68 \%$ health risk and by $49 \%$ food waste for an increase of $9 \%$ of the energy consumption (action 2). Efforts should be focused on consumers' awareness of the domestic storage conditions as many studies previously pointed out temperature abuses in the domestic refrigerator (Roccato, Uyttendaele, \& Membré, 2017), and the lack of knowledge of consumers about recommended domestic storage temperature (Jelena et al., 2016; Jevšnik, Hlebec, \& Raspor, 2008; McCarthy et al., 2007). Literature also pointed out that even when consumers were aware of the recommended temperature, they were not all aware of the temperature of their own domestic refrigerator (Alberto et al., 2014; Marklinder, Lindblad, Eriksson, Finnson, \& Lindqvist, 2004), which was often higher than the recommended one (Jelena et al., 2016).

Although thermostat-setting temperature has a high impact on food safety and food waste with limited impact on the total energy consumption attributed to the product (actions 2 and 3), opposite results were observed regarding the modification of the airflow rate in the display cabinet. It slightly impacts health risk and food waste whereas energy consumption appears to be more sensitive. In actions 6 and 7, the airflow rate was respectively decreased and increased by $25 \%$, resulting in around $1 \%$ variation in health risk and food waste and $16 \%$ variation in energy consumption. Reducing the airflow rate in the display cabinet by $50 \%$ would allow an energy preservation of $30 \%$ for less than a $2 \%$ increase in the health risk and food waste. However, the efficiency of the measure would be guaranteed only if the air curtain operates properly with a reduced airflow and more study would have to be conducted on its stability. As expected, increasing the thermal insulation of the domestic refrigerator reduced all criteria.

\subsubsection{Results of the Cost}

Food waste represents the major contribution to the total cost compared with energy consumption and DALY. Those results are consistent with the literature because in the United States, food waste is estimated at $\$ 218$ billion, whereas foodborne illness annually costs $\$ 50$ billion (Mercier, Villeneuve, Mondor, \& Uysal, 2017). However, no robust estimation was found in the literature regarding the energy consumption cost attributed to refrigeration for the food cold chain. Two actions allow the reduction of the total cost compared to the baseline (actions 2 and 4). The cost of action 2 represents half the cost of the baseline, mainly driven by the reduction of food waste. A better insulation of the domestic fridge (action 4) decreases the cost to $94 \%$ of the reference. Increasing the thermostat of the domestic refrigerator lead to a $35 \%$ augmentation of the cost compared with the baseline. Similar results were obtained by increasing the thermostat in the display cabinet by $2.5^{\circ} \mathrm{C}$ (action 8 ). Interestingly, the modification of the airflow rate in the display cabinet doesn't seem to have any impact on the global cost (actions 5,6, and 7) because the financial benefits are compensated by losses (Table IV).

\subsubsection{Comparison of Two MCDA Methods: AHP and ELECTRE III}

The results obtained with the two tested MCDA methods are slightly different (Figs. 4 and 5). Although both methods show that the reduction of the temperature in the domestic refrigerator (action 2) is the best action given the three criteria of health risk, food waste, and energy consumption, this conclusion is much clearer in the AHP method, whereas in the ELECTRE III method, actions 4 and 5 appear to have good scores. The impact of the weight is different according to the selected method. In the AHP method, the weight clearly impacts the score of the best and worse actions, respectively, actions 2 and 3 , whereas the impact on the other actions is limited (Fig. 5(b). For the ELECTRE III method, all action scores are more or less impacted by the weight, except for action 2. Although a high number of MCDA methods were developed, only two of the most common were used in this study (ELECTRE III and AHP). Cinelli et al. (2014) reported that researchers 
do not usually properly define the reasons for choosing a certain MCDA instead of another. Familiarity and affinity with a certain approach seem to be the drivers for the choice of a certain procedure. Two major drawbacks make the use AHP somewhat difficult. First, the model depends strongly on the scale of each criteria. Two different scales may lead to two completely different rankings. Then, a very negative valuation of an intervention on a criterion may be offset by positive valuations of this same intervention on other criteria, leading to a compensation bias. The ELECTRE III method allows the possibility for the decisionmakers to set indifference, preference, and veto values. In the context of food policy, the possibility to set veto values for the criteria in the ELECTRE III method may be useful to account for the adverse effect of an action. This method option appears to be promising in food policy as food safety might be seen as predominant with regard to food sustainability (Marucheck, Greis, Mena, \& Cai, 2011). The decisionmaker may set a stricter veto value for the health risk criteria. However, this hierarchy is not obvious for all stakeholders (Guillier et al., 2016). We considered that the analysis of the sensitivity of the indifference, preference, and veto values was out of the scope of this study but it has to be emphasized that the values of those parameters may impact the final results.

\subsubsection{Analysis of the MCDA and CBA Approaches}

The pure economical approach based on the CBA concluded, as for MCDA, that decreasing the thermostat of the domestic refrigerator to $4{ }^{\circ} \mathrm{C}$ seems to be the best compromise between health risk, food waste, and energy consumption. The advantage of the CBA compared to MCDA is that it permits to determine which scenarios are cost effective. It is worth notice that only two out of the seven interventions would be cost effective. Yet, in this study, only three criteria were included. The application of the CBA approach may be compromised if more criteria would have to be included, for which cost data are not always available or robust; for example, cost associated with trade impact (Ruzante et al., 2017). In the same way, the cost associated to human cases could have been more important. The cost per DALY used mainly relies on direct costs, direct nonhealth-care costs, and productivity losses from missed work (ANSES, 2015; Havelaar et al., 2012). Other approaches such as willingness to pay (Hoff- mann, Maculloch, \& Batz, 2015) could have led to higher cost. Moreover, as discussed in the limitations of the model, results of predictive models may vary in the absolute scale compared to what could be expected in reality, but the relative impact between the actions and the conclusions are expected to be robust and generalizable. In other words, the CBA is more sensitive to the uncertainty of the results compared with the MCDA methods that use pairwise comparisons or an outranking approach to rank the actions. Results of this study show the importance in food policy to consider aspects other than food safety that could be impacted by an action. MCDA can be a useful tool to support decisionmakers in food policy issues involving various qualitative as well as quantitative outputs. This aspect of this method appears to be promising in food policy as food safety might be seen as predominant with regard to food sustainability (Marucheck et al., 2011), and because this hierarchy is not obvious for all stakeholders (Guillier et al., 2016).

\section{CONCLUSION}

This article proposes an original multidisciplinary approach linking prediction of product temperature in refrigeration processes, energy consumption, and predictive microbiology. More precisely, this study focuses on the cold chain of ham, including refrigerated transportation, storage in supermarket cold room, display cabinet, transport by consumer, and domestic refrigerator. The model developed allowed to measure the impact of several potential actions that are not compliant with current regulations, technical specification of equipment, or practices of consumers. Three criteria were investigated: risk for human health, food waste, and energy consumption. Moreover, three methods that could be used to assist decision making were tested. The three methods, a CBA and two MCDA methods, were used to rank the different actions considered. Although ELECTRE III appears to be promising to take into account the adverse effect of an action, results of the three methods were similar and highlighted the importance of setting the thermostat of the domestic refrigerator at $4{ }^{\circ} \mathrm{C}$. Interestingly, results show that the modification of the airflow rate in the display cabinet might reduce energy consumption without a high adverse effect on food waste and food safety. Other criteria, products, and previous stages of the cold chain will be implemented in the model in future work. The implementation of MCDA can be a useful tool to support 
decision making in food policy on issues involving various qualitative as well as quantitative conflicting outputs.

\section{ACKNOWLEDGMENTS}

The research leading to this article has received funding from the French National Research Agency (Opticold Project, ANR-15-CE21-0011-02).

\section{REFERENCES}

Adunlin, G., Diaby, V., Montero, A. J., \& Xiao, H. (2015). Multicriteria decision analysis in oncology. Health Expectations: An International Journal of Public Participation in Health Care and Health Policy, 18(6), 1812-1826.

Alberto, V., Anna, R. F., Pierluigi, D. C., Claudia, C., Luca, P., \& Adriana, I. (2014). The management of the domestic refrigeration: Microbiological status and temperature. British Food Journal, 116(6), 1047-1057.

Alvarez, G. (2015). Cold chain refrigeration innovations the FRISBEE project. Journal of Food Engineering, 148, 1.

Anderson, M., Jaykus, L. -A., Beaulieu, S., \& Dennis, S. (2011). Pathogen-produce pair attribution risk ranking tool to prioritize fresh produce commodity and pathogen combinations for further evaluation (P3ARRT). Food Control, 22(12), 18651872.

Angelis, A., \& Kanavos, P. (2017). Multiple criteria decision analysis (MCDA) for evaluating new medicines in health technology assessment and beyond: The advance value framework. Social Science \& Medicine, 188(Supplement C), 137-156.

Anonymous. Energie verbraucher. Tipp 12: Kühlschrank auf $7{ }^{\circ} \mathrm{C}$ einstellen, Retrieved from https://www.energieverbrau cher.de/de/tipp12-kuehltemperatur_1959/.

Anonymous. (2007). 50 years of food safety in the European Union. Office for Official Publications of the European Communities.

Anonymous. (2015). Fermeture des meubles frigorifiques de vente à température positive. BAT-EQ-124. Journal officiel de la république française - $N^{\circ} 75$ du 29 mars 2015. Retrieved from https://atee.fr/sites/default/files/bat-eq-124-fermeture_ meubles_frigorifiq_de_vente_a_temperature_positive.pdf.

Anonymous. (2018). Prix de l'électricité en France et dans l'Union européenne en 2016 - Commissariat général au développement durable - Ministère de la transition écologique et solidaire. Retrieved from https://www.statistiques.developpement-durable. gouv.fr/fileadmin/documents/Produits_editoriaux/Publications/ Datalab_essentiel/2018/datalab-essentiel-132-prix-electricite2016-janvier2018.pdf.

Augustin, J. -C., Bergis, H., Midelet-Bourdin, G., Cornu, M., Couvert, O., Denis, C., ... Stahl, V. (2011). Design of challenge testing experiments to assess the variability of Listeria monocytogenes growth in foods. Food Microbiology, 28(4), 746-754.

Baranyi, J., \& Buss da Silva, N. (2017). The use of predictive models to optimize risk of decisions. International Journal of Food Microbiology, 240, 19-23.

Baranyi, J., \& Roberts, T. A. (1994). A dynamic approach to predicting bacterial growth in food. International Journal of Food Microbiology, 23(3-4), 277-294.

Belton, V., \& Stewart, T. (2002). Multiple criteria decision analysis-An integrated approach. Boston: Kluwer Academic Publishers.

Cemagref, \& ANIA. (2004). La chaîne du froid: Du fabricant au consommateur: Les résultats de l'audit menée par le Cemagref pour l'ANIA. Revue Générale du Froid, 1042, 29-36.
Cinelli, M., Coles, S. R., \& Kirwan, K. (2014). Analysis of the potentials of multi criteria decision analysis methods to conduct sustainability assessment. Ecological Indicators, 46(Supplement C), $138-148$.

Coulomb, D. (2008). Refrigeration and cold chain serving the global food industry and creating a better future: Two key IIR challenges for improved health and environment. Trends in Food Science \& Technology, 19(8), 413-417.

Doyle, M. P., Erickson, M. C., Alali, W., Cannon, J., Deng, X., Ortega, Y., ... Zhao, T. (2015). The food industry's current and future role in preventing microbial foodborne illness within the United States. Clinical Infectious Diseases, 61(2), 252-259.

Duret, S., Guillier, L., Hoang, H.-M., Flick, D., \& Laguerre, O. (2014). Identification of the significant factors in food safety using global sensitivity analysis and the accept-and-reject algorithm: Application to the cold chain of ham. International Journal of Food Microbiology, 180(Supplement C), 39-48.

Duret, S., Gwanpua, S. G., Hoang, H. -M., Guillier, L., Flick, D., Laguerre, O.,... Geeraerd, A. (2015). Identification of the significant factors in food quality using global sensitivity analysis and the accept-and-reject algorithm. Part III: Application to the apple cold chain. Journal of Food Engineering, 148(Supplement C), 66-73.

Duret, S., Pouillot, R., Fanaselle, W., Papafragkou, E., Liggans, G., Williams, L., \& Van Doren, J. M. (2017). Quantitative risk assessment of norovirus transmission in food establishments: Evaluating the impact of intervention strategies and food employee behavior on the risk associated with norovirus in foods. Risk Analysis, 37(11), 2080-2106.

Ercsey-Ravasz, M., Toroczkai, Z., Lakner, Z., \& Baranyi, J. (2012). Complexity of the international agro-food trade network and its impact on food safety. PLOS ONE, 7(5), e37810.

European Food Safety Authority. (2018). Listeria monocytogenes contamination of ready-to-eat foods and the risk for human health in the EU. EFSA Journal 2018, 16(1). https://doi.org/10.2903/j.efsa.2018.5134.

Fazil, A., Rajic, A., Sanchez, J., \& McEwen, S. (2008). Choices, choices: The application of multi-criteria decision analysis to a food safety decision-making problem. Journal Food Protection, 71(11), 2323-2333.

Figueira, J., Mousseau, V., \& Roy, B. (2016). ELECTRE methods multiple criteria decision analysis: State of the art surveys. 2nd ed. New York: Springer.

Flick, D., Hoang, H. M., Alvarez, G., \& Laguerre, O. (2012). Combined deterministic and stochastic approaches for modeling the evolution of food products along the cold chain. Part I: Methodology. International Journal of Refrigeration, 35(4), 907914.

Food and Agriculture Organization for the United Nations/World Health Organization. (1999). Risk assessment of microbiological hazards in foods. Report of Joint FAO/WHO Expert Consultation Geneva, Switzerland, 15-19 March 1999. World Health Organization, Geneva, Switzerland, 1999.

France Weather Forecast. (2002). Daily record in 47 regions at 8 am and at $17 \mathrm{pm}$ from June to October 2002.

French Agency for Food, Environmental and Occupational Health \& Safety. (2015). Information des consommateurs en matière de prévention des risques microbiologiques liés aux aliments-Saisine 2012-SA-0118. Retrieved from https://www. anses.fr/fr/system/files/BIORISK2012sa0118Ra-01.pdf.

French Agency for Food, Environmental and Occupational Health \& Safety. (2017). Etude individuelle des consommations alimentaires 3 (INCA 3 ). Retrieved from https://www.anses.fr/fr/system/files/NUT2014SA0234Ra.pdf.

Goodman, M. K., Maye, D., \& Holloway, L. (2010). Ethical foodscapes?: Premises, promises, and possibilities. Environment and Planning A, 42(8), 1782-1796.

Goulet, V., Hebert, M., Hedberg, C., Laurent, E., Vaillant, V., De Valk, H., \& Desenclos, J. C. (2012). Incidence of listeriosis and 
related mortality among groups at risk of acquiring listeriosis. Clinical Infectious Disease, 54(5), 652-660.

Greco, S., Ehrgott, M., \& Figueira, J. (2016). Multiple criteria decision analysis - State of the art surveys. New York: Springer.

Guillier, L., Duret, S., Hoang, H.-M., Flick, D., Nguyen-Thé, C., \& Laguerre, O. (2016). Linking food waste prevention, energy consumption and microbial food safety: The next challenge of food policy? Current Opinion in Food Science, 12, 30-35.

Havelaar, A. H., Haagsma, J. A., Mangen, M. J., Kemmeren, J. M., Verhoef, L. P., Vijgen, S. M., ... van Pelt, W. (2012). Disease burden of foodborne pathogens in the Netherlands, 2009. International Journal of Food Microbiology, 156(3), 231-238.

Havelaar, A. H., van Rosse, F., Bucura, C., Toetenel, M. A., Haagsma, J. A., Kurowicka, D.,... Braks, M. A. (2010). Prioritizing emerging zoonoses in the Netherlands. PLOS ONE, 5(11), e13965.

Hoang, H. M., Flick, D., Derens, E., Alvarez, G., \& Laguerre, O. (2012). Combined deterministic and stochastic approaches for modelling the evolution of food products along the cold chain. Part II: A case study. International Journal of Refrigeration, 35(4), 915-926.

Hoang, M. H., Laguerre, O., Moureh, J., \& Flick, D. (2012). Heat transfer modelling in a ventilated cavity loaded with food product: Application to a refrigerated vehicle. Journal of Food Engineering, 113(3), 389-398.

Hoffmann, S., Maculloch, B., \& Batz, M. (2015). Economic burden of major foodborne illnesses acquired in the United States. Current Politics and Economics of the United States, Canada and Mexico, 17(4), 543.

Hueston, W., \& McLeod, A. (2012). Overview of the global food system: Changes over time/space and lessons for the future food safety. In Institute of Medicine (US). Improving food safety through a one health approach: Workshop summary. Washington, DC: National Academics Press. A5.

Humphries Choptiany, J. M., \& Pelot, R. (2014). A multicriteria decision analysis model and risk assessment framework for carbon capture and storage. Risk Analysis, 34(9), 1720-1737.

Institut du porc. (2010). Rapport d'études: Impact des baisses en sel et gras sur des paramètres de conservation des produits transformés. Institut du porc, Pôle Viandes Fraîches et Produits Transformés, www.ifip.asso.fr. Maisons-Alfort. Retrieved from www.ifip.asso.fr.

Institut National de la Statistique et des Etudes Economiques. (2018). Prix moyen mensuels de vente au détail en métropolejambon supérieur $(1 \mathrm{~kg})$. Retrieved from https://www.insee.fr/fr/ statistiques/serie/000849397.

International Institute of Refrigeration. (2009). The role of refrigeration in worldwide nutrition-5th informatory note on refrigeration and food. Paris: International Institute of Refrigeration.

James, S. J., \& James, C. (2010). The food cold-chain and climate change. Food Research International, 43(7), 19441956.

Jelena, J., Vera, K., Jelena, I., Marija, B., Marija, S., Nataša, G., \& Milan, Ž. B. (2016). Temperatures, cleanliness and food storage practises in domestic refrigerators in Serbia, Belgrade. International Journal of Consumer Studies, 40(3), 276-282.

Jevšnik, M., Hlebec, V., \& Raspor, P. (2008). Consumers' awareness of food safety from shopping to eating. Food Control, 19(8), 737-745.

Laguerre, O., Duret, S., Hoang, H. M., \& Flick, D. (2014). Using simplified models of cold chain equipment to assess the influence of operating conditions and equipment design on cold chain performance. International Journal of Refrigeration, 47, 120-133.

Laguerre, O., Duret, S., Hoang, H. M., Guillier, L., \& Flick, D. (2015). Simplified heat transfer modeling in a cold room filled with food products. Journal of Food Engineering, 149(Supplement C), 78-86.
Laguerre, O., \& Flick, D. (2010). Temperature prediction in domestic refrigerators: Deterministic and stochastic approaches. International Journal of Refrigeration, 33, 41-51.

Laguerre, O., Hoang, H. M., \& Flick, D. (2013). Experimental investigation and modelling in the food cold chain: Thermal and quality evolution. Trends in Food Science \& Technology, 29(2), 87-97.

Lake, R. J., Cressey, P. J., Campbell, D. M., \& Oakley, E. (2010). Risk ranking for foodborne microbial hazards in New Zealand: Burden of disease estimates. Risk Analysis, 30(5), 743752.

Linkov, I., Satterstrom, F. K., Kiker, G., Seager, T. P., Bridges, T., Gardner, K. H.,... Meyer, A. (2006). Multicriteria decision analysis: A comprehensive decision approach for management of contaminated sediments. Risk Analysis, 26(1), 61-78.

Linkov, I., Welle, P., Loney, D., Tkachuk, A., Canis, L., Kim, J. B., \& Bridges, T. (2011). Use of multicriteria decision analysis to support weight of evidence evaluation. Risk Analysis, 31(8), 1211-1225.

Mangen, M. J., Havelaar, A. H., Poppe, K. P., \& de Wit, G. A. (2007). Cost-utility analysis to control Campylobacter on chicken meat: Dealing with data limitations. Risk Analysis, 27(4), 815-830.

Marklinder, I. M., Lindblad, M., Eriksson, L. M., Finnson, A. M., \& Lindqvist, R. (2004). Home storage temperatures and consumer handling of refrigerated foods in Sweden. Journal of Food Protection, 67(11), 2570-2577.

Marucheck, A., Greis, N., Mena, C., \& Cai, L. (2011). Product safety and security in the global supply chain: Issues, challenges and research opportunities. Journal of Operations Management, 29(7), 707-720.

Mataragas, M., \& Drosinos, E. H. (2007). Shelf life establishment of a sliced, cooked, cured meat product based on quality and safety determinants. Journal of Food Protection, 70(8), 18811889.

Mataragas, M., Drosinos, E. H., Vaidanis, A., \& Metaxopoulos, I. (2006). Development of a predictive model for spoilage of cooked cured meat products and its validation under constant and dynamic temperature storage conditions. Journal of Food Science, 71(6), M157-M167.

Mattarolo, L. (1990). Refrigeration and food processing to endure the nutrition of the growing world population. In Progress in the science and technology of refrigeration in food engineering, proceedings of meetings of commissions B2, C2, D1, D2-D3, September 24-28, 1990 (pp. 43-54). Dresden, Germany.

Mazzocchi, M., Ragona, M., \& Zanoli, A. (2013). A fuzzy multicriteria approach for the ex-ante impact assessment of food safety policies. Food Policy, 38(Supplement C), 177-189.

McCarthy, M., Brennan, M., Kelly, A. L., Ritson, C., de Boer, M., \& Thompson, N. (2007). Who is at risk and what do they know? Segmenting a population on their food safety knowledge. Food Quality and Preference, 18(2), 205-217.

Mejlholm, O., \& Dalgaard, P. (2013). Development and validation of an extensive growth and growth boundary model for psychrotolerant Lactobacillus spp. in seafood and meat products. International Journal of Food Microbiology, 197(2), 244-260.

Mejlholm, O., Gunvig, A., Borggaard, C., Blom-Hanssen, J., Mellefont, L., Ross, T.,... Dalgaard, P. (2010). Predicting growth rates and growth boundary of Listeria monocytogenes: An international validation study with focus on processed and ready-to-eat meat and seafood. International Journal of Food Microbiology, 141(3), 137-150.

Mercier, S., Villeneuve, S., Mondor, M., \& Uysal, I. (2017). Timetemperature management along the food cold chain: A review of recent developments. Comprehensive Reviews in Food Science and Food Safety, 16(4), 647-667.

Meyer, P., Bigaret, S., Hodgett, R., \& Olteanu, A., L. (2018). Functions to support the multicriteria decision aiding process. 
Retrieved from https://github.com/paterijk/MCDA, Accessed on July 12, 2018.

Ovca, A., \& Jevsnik, M. (2009). Maintaining a cold chain from purchase to the home and at home: Consumer opinions. Food Control, 20(2), 167-172.

Papadopoulos, A., Sioen, I., Cubadda, F., Ozer, H., Oktay Basegmez, H. I., Turrini, A.,... Sirot, V. (2015). TDS exposure project: Application of the analytic hierarchy process for the prioritization of substances to be analyzed in a total diet study. Food and Chemical Toxicology, 76(Supplement C), 46-53.

Pouillot, R., Albert, I., Cornu, M., \& Denis, J.-B. (2003). Estimation of uncertainty and variability in bacterial growth using Bayesian inference. Application to Listeria monocytogenes. International Journal of Food Microbiology, 81(2), 87-104.

Pouillot, R., Gallagher, D., Tang, J., Hoelzer, K., Kause, J., \& Dennis, S. B. (2015). Listeria monocytogenes in retail delicatessens: An interagency risk assessment-model and baseline results. Journal of Food Protection, 78(1), 134-145.

Pouillot, R., Goulet, V., Delignette-Muller, M. L., Mahe, A., \& Cornu, M. (2009). Quantitative risk assessment of Listeria monocytogenes in French cold-smoked salmon: II. Risk characterization. Risk Analysis, 29(6), 806-819.

Pouillot, R., Hoelzer, K., Chen, Y., \& Dennis, S. B. (2015). Listeria monocytogenes dose response revisited-Incorporating adjustments for variability in strain virulence and host susceptibility. Risk Analysis, 35(1), 90-108.

Pouillot, R., \& Lubran, M. B. (2011). Predictive microbiology models vs. modeling microbial growth within Listeria monocytogenes risk assessment: What parameters matter and why. Food Microbiology, 28(4), 720-726.

$\mathrm{R}$ Core Team. (2016). $R$ : A language and environment for statistical computing. Vienna, Austria: R Foundation for Statistical Computing. Retrieved from https://www.R-project.Org/.

Ragaert, P., Verbeke, W., Devlieghere, F., \& Debevere, J. (2004). Consumer perception and choice of minimally processed vegetables and packaged fruits. Food Quality and Preference, 15(3), 259-270.

Roccato, A., Uyttendaele, M., \& Membré, J. -M. (2017). Analysis of domestic refrigerator temperatures and home storage time distributions for shelf-life studies and food safety risk assessment. Food Research International, 96, 171-181.

Rosario, L., Howell, R.H., Elovitz, K., \& Burdwood, B. (2001). Relative humidity and temperature measurements and predictions in supermarkets. Transactions of ASHRAE, 107(2), 415423.
Roy, B. (1978). ELECTRE III: Un algorithme de classements fondé sur une représentation floue des préférences en présence de critères multiples, Cahiers du Centre d'Etudes de Recherche Opérationelle, 20(1), 3-24.

Roy, B. (1991). The outranking approach and the foundations of ELECTRE Methods. Theory and Decision, 31, 4973.

Ruzante, J. M., Davidson, V. J., Caswell, J., Fazil, A., Cranfield, J. A. L., Henson, S. J., .. Farber, J. M. (2010). A multifactorial risk prioritization framework for foodborne pathogens. Risk Analysis, 30(5), 724-742.

Ruzante, J. M., Grieger, K., Woodward, K., Lambertini, E., \& Kowalcyk, B. (2017). The use of multi-criteria decision analysis in food safety risk-benefit assessment. Food Protection Trends, 37(2), 132-139.

Saaty, T. L. (1980). The analytical hierarchy process. New York: McGraw-Hill.

Saaty, T. L. (2005). The analytic hierarchy and analytic network processes for the measurement of intangible criteria and for decision-making multiple criteria decision analysis: State of the art surveys (Vol. 78). New York: Springer.

Stenmarck, Å., Jensen, C., Quested, T., \& Moates, G. (2016). Estimates of European food waste levels. European Commission (FP7), Coordination and Support Action-CSA. Retrieved from https://ec.europa.eu/food/safety/food_waste_en.

U.S. Food and Drug Administration. (2015). Multicriteria-based ranking model for risk management of animal drug residues in milk and milk products. Retrieved from https://www.fda.gov/ downloads/Food/FoodScienceResearch/RiskSafetyAssessment/ UCM444035.pdf.

Uyttendaele, M., De Troy, P., \& Debevere, J. (1999). Incidence of Listeria monocytogenes in different types of meat products on the Belgian retail market. International Journal of Food Microbiology, 53(1), 75-80.

Wiseman, S. R. (2015). The implementation of the Food Safety Modernization Act and the strength of the sustainable agriculture movement. American Journal of Law \& Medicine, 41(2-3), 259-273.

Yemshanov, D., Koch, F. H., Ben-Haim, Y., Downing, M., Sapio, F., \& Siltanen, M. (2013). A new multicriteria risk mapping approach based on a multiattribute frontier concept. Risk Analysis, 33(9), 1694-1709.

Zanoni, S., \& Zavanella, L. (2012). Chilled or frozen? Decision strategies for sustainable food supply chains. International Journal of Production Economics, 140(2), 731-736. 